\title{
Arquitectura en la encrucijada. La adaptación de los modelos constructivos hispanos a las iglesias de Panamá (siglo XVI)*
}

\section{Architecture at the Crossroads. The Adaptation of Spanish Church Construction Models in $16^{\text {th }}$-century Panama}

\author{
Juan Luis Blanco Mozo \\ ORCID iD: https://orcid.org/0000-0003-1979-3242 \\ Universidad Autónoma de Madrid, España
}

Un aspecto poco conocido de la colonización americana fue la implantación y el desarrollo de la arquitectura religiosa hispana en Tierra Firme. Llegó al continente como lo hizo a las islas caribeñas, de la mano de la nueva organización eclesiástica diseñada por la Corona según el modelo sevillano. Sin embargo, su plasmación fue muy tardía y desigual, condicionada por diferentes factores que se analizan en este estudio. Sufrió asimismo un proceso de adaptación al medio americano difícil de interpretar a la luz de los escasos testimonios materiales que han llegado a nuestros días.

Palabras clave: Arquitectura española; Colonización; Panamá; Arquitectura de la madera; Bohío.

A little-known aspect of the colonization of the Americas was the implementation and development of Spanish religious architecture in the New World. It reached the Spanish Main as it had the islands of the Caribbean, through the ecclesiastical organization instigated by the Crown, based on the Seville model. Nevertheless, its materialization was protracted and erratic due to a series of factors analyzed in this study. This process of adaptation to the American milieu is somewhat difficult to interpret as a result of the scarcity of the materials that have survived to the present day.

KeYwords: Spanish Architecture; Colonization; Panamá; Wooden Architecture; Bohío.

Copyright: (C) 2020 CSIC. Este es un artículo de acceso abierto distribuido bajo los términos de la licencia de uso y distribución Creative Commons Reconocimiento 4.0 Internacional (CC BY 4.0).

* Agradezco a Bethany Aram y Juan Guillermo Martín los comentarios y recomendaciones que han permitido la mejora sustancial del texto. El agradecimiento ha de extenderse a todos los investigadores que forman parte del proyecto de investigación An Artery of Empire. Conquest, commerce, crisis, culture and the Panamanian Junction (1513-1671) (ERC CoG 648535). 
Escribir sobre la arquitectura religiosa panameña del siglo XVI significa hacerlo sobre una realidad material prácticamente inexistente que, sin embargo, ha dejado su memoria tejida en infinidad de documentos que se conservan en el Archivo General de Indias. El abandono en 1524 de Santa María la Antigua del Darién, primera capital de Tierra Firme, y la destrucción en 1671 de Panamá la Vieja, nos ha privado de conocer la mayor parte del patrimonio arquitectónico erigido a lo largo de aquella centuria. La propia materialidad de estos templos, construidos en madera, favoreció su desaparición. No pocos de ellos perecieron bajo las llamas de los incendios que de cuando en cuando asolaron la primera fundación panameña. A medida que el lento pero inexorable proceso de petrificación se abría paso en la misma, auspiciado por las autoridades españolas, otras iglesias fueron demolidas para dejar paso a la arquitectura de cal y canto.

El análisis formal de la arquitectura tampoco ayuda demasiado. Presenta unas limitaciones insalvables cuando se aplica a las construcciones virreinales panameñas. Casi se podría decir que ciertos condicionantes históricos presentes en estas latitudes hacen imposible la utilización de los trasnochados criterios estilísticos. La llegada tardía de las soluciones clasicistas procedentes de la arquitectura hispana imposibilita su encaje en el marco cronológico en el que estas se desarrollaron en la Península, pero lejos de ser fenómenos de pervivencia como podría pensarse, su plasmación práctica dista mucho de los arquetipos empleados en la edilicia española. Algunas de estas particularidades vinieron dadas, según parece, por la escasa cualificación artística —que no técnica- de los profesionales de la construcción empleados en Panamá, que no acertaron a plantear correctamente la sintaxis del clasicismo. Un uso, por lo tanto, que no ha de ser entendido como el desarrollo de unas licencias planteadas desde el conocimiento de la norma clásica, por así decirlo, en clave manierista, sino desde la inexperiencia y la impericia en el manejo de este lenguaje. Esta falta de encaje en el sistema de los estilos - no olvidemos, un paradigma historiográfico nacido a posteriori para clasificar la arquitectura del viejo continente- no le resta ningún mérito a la arquitectura panameña. Es más, le dota de un interés inusitado por contener unos ingredientes peculiares ajenos a la tradición europea de la que supuestamente se ha pensado que procede. Resta pues circunscribir su plasmación y desarrollo dentro de su contexto histórico preciso, en el que los criterios ambientales — por expresarlo de alguna forma- ejercieron tanta influencia en ella. 


\section{El bohío y la primera arquitectura española}

Hay que considerar al «bohío» como una construcción vernácula americana en sus diferentes acepciones y tipologías, que nació de la perfecta adaptación del ser humano a las condiciones medioambientales. Se caracterizó por ser una forma arquitectónica de extraordinaria simpleza, tramada exclusivamente con materiales de recolección provenientes de la naturaleza, que apenas sufrían transformaciones antes de incorporarse a este sistema constructivo. Llamaron la atención de Gonzalo Fernández de Oviedo (1478-1557), quien describió detalladamente y con sus propias palabras la construcción de las viviendas de los indígenas de La Española, muy similares a las que encontraría en Tierra Firme. ${ }^{1}$ Captó las peculiaridades de esta sencilla arquitectura basada, a diferencia de la europea, en la ausencia de muros de carga. El perímetro del bohío se formaba con postes u horcones de madera hincados directamente en la tierra y separados por una distancia variable que se cerraba con cañas o palos bien remetidos —el baharequey a veces emparchados de barro. Las cabezas visibles de estos postes se unían con viguetas o, como dice Oviedo, «soleras» sobre las que cargaba la cubierta sellada con palmas o paja. Todas las uniones se realizaban con bejucos o fibras vegetales, tan alabadas por su resistencia y flexibilidad que «sirven de clavaçon e ligaçon en lugar de cuerdas y de clavos». ${ }^{2}$

Este tipo de construcciones fueron conocidas comúnmente como «bohíos», aunque en algunos lugares esta denominación se limitaba exclusivamente a las que tenían planta rectangular y cubierta a dos aguas, mientras que los «caneys» presentaban el perímetro circular y el techo cónico con un poste central que podía alcanzar mucha altura. Estos últimos recordaban al cronista madrileño, buen conocedor de la milicia, el «pabellón o tienda de campo, como se traen en los exércitos e reales en España e Italia». ${ }^{3}$ Las primeras representaciones de estas construcciones indígenas se publicaron en el libro sexto de la Historia General de las Indias (Sevilla, 1535) del mencionado Gonzalo Fernández de Oviedo. Sirvieron para ilustrar la descripción del caney (fig. 1a) y del bohío (fig. 2a) de los indios de La Española, este último considerado mejor «en la vista y de más aposento para hombres

1 Fernández de Oviedo, 1851 [1535-1549], I:163-164. Se ahorra la descripción de las viviendas de los indios de Tierra Firme remitiendo a lo expuesto sobre el mismo tema en La Española. Ibidem, 1853 [1535-1549], III:131.

2 Ibidem, 1851[1535-1549], I:164.

3 Idem. 


\section{REPRESENTACIONES DEL CANEY EN LAS OBRAS DE GONZALO FERNÁNDEZ DE OVIEDO (1535) Y LUIS JOSEPH PEGUERO (1762-1763)}

A

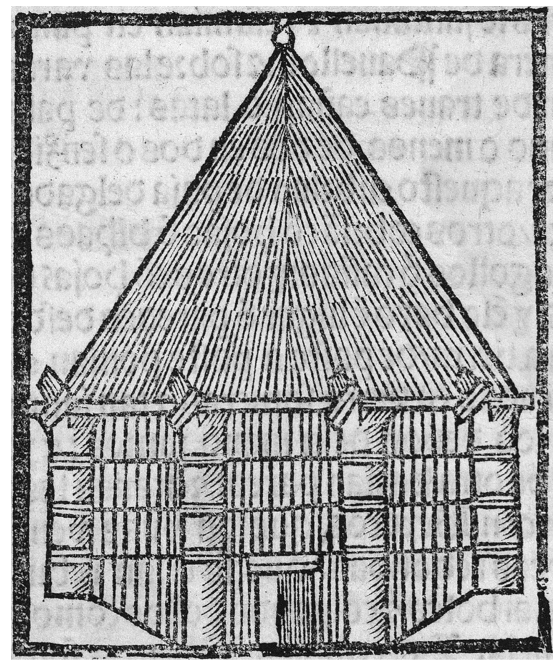

B

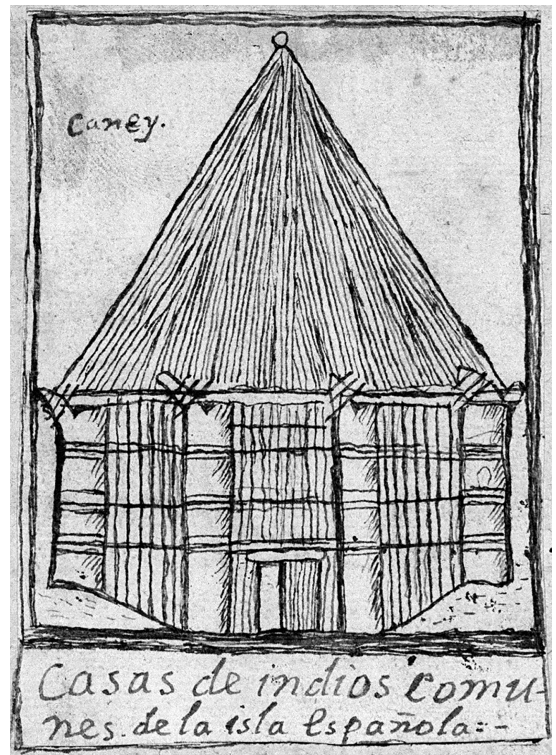

Fuente: Fernández de Oviedo, Historia general de las Indias, 1535, f. 58v (izquierda). Peguero, Historia de la conquista de la isla española de Santo Domingo, 1762-1763, BNE, ms. 1479, 36 (derecha). Imágenes propiedad de la Biblioteca Nacional de España.

más principales y caciques». ${ }^{4}$ Parece probable que su autor, siempre bien informado, manejara alguna copia manuscrita de la Relación de Rodrigo de Escobedo, escribano del primer viaje de Cristóbal Colón, ${ }^{5}$ en la que narraba la expedición llevada a cabo en diciembre de 1492 al gran poblado taíno de Guacanagarí, en cuya parte central, en torno a una plaza, los españoles hallaron el palacio del cacique, un «bugio» de veinticinco por ocho metros aproximadamente (treintaidós por diez varas), compartimentado en diferentes espacios; otro de treintaitrés metros de longitud que servía de guardia y cárcel, y un tercero utilizado como templo con una planta cuadrada de casi

4 Fernández de Oviedo, 1535, ff. 48-49r. Disponible en http://bdh-rd.bne.es/viewer. vm?id=0000252011\&page $=1$ [Consultado: $25 / 04 / 2020$ ].

5 Gould, 1984, 412-422. 
FIGURA 2

\section{REPRESENTACIONES DEL BOHÍO EN LAS OBRAS DE GONZALO FERNÁNDEZ DE OVIEDO (1535) Y LUIS JOSEPH PEGUERO (1762-1763)}

A

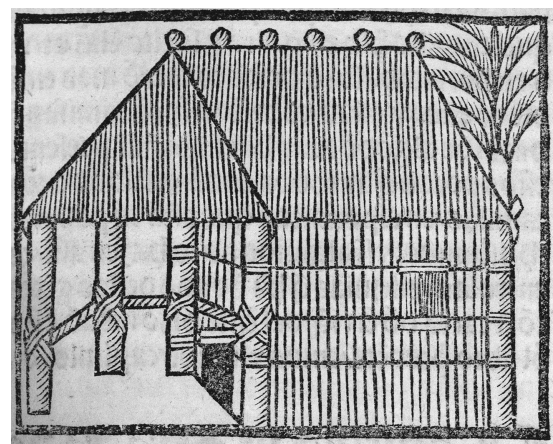

$\mathrm{B}$

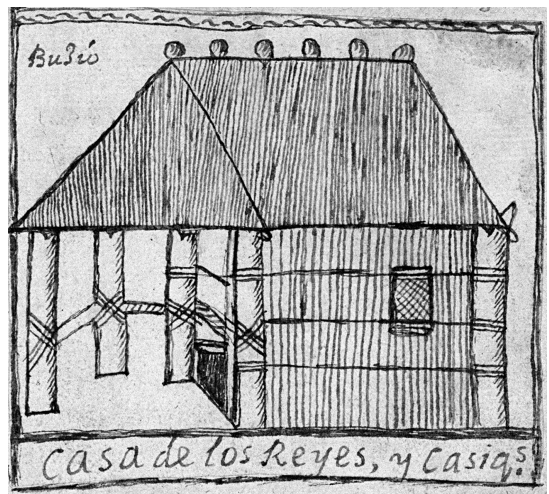

Fuente: Fernández de Oviedo, Historia general de las Indias, 1535, f. 59r (izquierda). Peguero, Historia de la conquista de la isla española de Santo Domingo, 1762-1763, BNE, ms. 1479, 35 (derecha). Imágenes propiedad de la Biblioteca Nacional de España.

diecisiete metros de lado. La Relación de Escobedo, escrita antes de que la carabela Santa María encallase en la costa dominicana y se creara el primer asentamiento hispano - el fallido Fuerte Navidad - en el Nuevo Mundo, se conoce a través de una copia incluida en la Historia de la conquista de la isla Española de Luis Joseph Peguero (1762), cuyo manuscrito, publicado en 1975, se conserva en la Biblioteca Nacional de España. ${ }^{6}$ En este último, Peguero copió también dos dibujos realizados al parecer por Pedro de Salcedo, paje de Colón: ${ }^{7}$ el caney (fig. 1b) o vivienda de los «indios comunes», y el bohío (fig. 2b) que servía de «casa de los reyes y caciques». ${ }^{8}$ Es muy probable que los dibujos desaparecidos de Salcedo sirvieran de modelo a las entalladuras que insertó Fernández de Oviedo en su obra arriba citada. ${ }^{9}$

6 Peguero, 1975 [orig. 1762 -1763], I:37-43.

7 Gould, 1984, 229-245.

8 Luis Joseph Peguero, Historia de la conquista de la isla española de Santo Domingo, traducida de la Historia General de las Indias, escrita por Antonio de Herrera, y de otros autores que han escrito sobre el particular, 1762 -1763, Biblioteca Nacional de España, Madrid (BNE), ms. 1479, 35-36. Disponible en: http://bdh-rd.bne.es/viewer.vm?id=0000010189\&page=1 [Consultado: 25/04/2020].

9 Como se argumenta en Prieto Vicioso, 2016, 270. Sobre el bohío, ver además Prieto Vicioso, 2008, 113-150; Soraluce Blond, 2003, 144-147. 
El bohío en todas sus variedades fue la tipología constructiva más habitual en Tierra Firme, donde los españoles también hallaron en menor medida palafitos y las casas-nido o barbacoas. Algunos de estos bohíos podían alcanzar gran tamaño, como el de planta circular del cacique de Veraguas, capaz de albergar a más de 300 personas y que fue bautizado por los españoles de la expedición de Lope de Olano como Santa María la Redonda. ${ }^{10}$ Espaciosos y bien construidos «con chapiteles muy altos» que apenas ofrecían resistencia a los fuertes vientos, eran los bohíos también «circulares» descritos por Fernández de Oviedo en Natá. ${ }^{11}$ Por ser construcciones perecederas en las que no se empleaba la piedra, más que en ocasiones para ajustar los horcones en el suelo, apenas se han conservado restos arqueológicos de estas estructuras que, ${ }^{12}$ como se ha señalado, podían alcanzar una cierta complejidad constructiva. La etnografía comparada ha constatado la existencia de bohíos de gran tamaño que hasta hace muy poco tiempo servían como lugar de reunión a los indios del Darién. ${ }^{13}$ Los colonizadores emplearon esta sencilla tipología constructiva para levantar sus primeras viviendas en el Nuevo Mundo. La Isabela, la primera ciudad fundada en La Española, de existencia efímera (1494-1498), contó con un buen número de bohíos que dieron cobijo a sus nuevos pobladores. En Santa María la Antigua del Darién sucedió lo mismo. Los españoles supieron valorar las ventajas ofrecidas por los bohíos utilizando la misma técnica para levantar edificios de mayor capacidad como el «toldo», que sirvió como almacén de la hacienda real en la primera capital del istmo. ${ }^{14}$

Según Fernández de Oviedo, sobre esta base tecnológica vernácula, los colonos peninsulares introdujeron dos cambios sustanciales en sus construcciones: la incorporación de la clavazón metálica, siempre en la medida de las posibilidades al ser cara y escasa en las Indias, y la transformación de la madera en tablas bien cortadas para aislar las viviendas. Con estos adelantos consiguieron elevar la altura de sus bohíos con sobrados y cuartos altos, y abrir ventanas en las paredes de tablazón, pues por lo general las casas de los indios carecían de vanos, a excepción de un acceso bajo y estrecho que les protegía de las amenazas exteriores. El mejor ejemplo de esta hibridación constructiva en torno a la madera nos lo ofrece el citado

10 Fernández de Oviedo, 1852 [1535-1549], II:468.

11 Ibidem, 1853 [1535-1549], III:131-132.

12 Martín, 2002, 215.

13 Gutiérrez, 1966, 62-68.

14 Fernández de Oviedo, 1853 [1535-1549], III:37. 
Oviedo, quien mandó edificar una residencia en Santa María la Antigua «que no tenía sino madera é cañas, é paja é alguna clavazón [...] con buenos aposentos altos e baxos». ${ }^{15}$

La primera arquitectura religiosa del Nuevo Mundo siguió las mismas pautas que la construcción civil. Las primitivas iglesias de La Española y Tierra Firme se alojaron en sencillos bohíos que en algunos casos se adaptaron a las necesidades del culto. Esta primera fase de provisionalidad estaba llamada a desaparecer una vez que se iniciara el proceso de urbanización de las nuevas ciudades que vino aparejado a la organización de los incipientes obispados indianos. Las autoridades españolas aspiraron a crear sedes catedralicias a imagen y semejanza de las peninsulares. Sin embargo, este proceso de consolidación de la arquitectura no fue tan sencillo. Estuvo condicionado por la disponibilidad de recursos económicos, de materiales de construcción (cal, piedra o ladrillo) y de maestros con la suficiente capacitación técnica.

No sucedió lo mismo con las iglesias de los indígenas. Las leyes de Burgos de 1512 y sus adiciones de 1513 reconocieron al bohío como la tipología más adecuada para levantar los templos de los indios sometidos a la encomienda. ${ }^{16}$ Las ordenanzas de Pedrarias, promulgadas como gobernador de Castilla del Oro en 1521 y 1522, rectificaron algunos aspectos de aquellas como, por ejemplo, lo referente a la presencia de los encomenderos en los poblados de los indios y no al revés, como se estipulaba en las primeras. ${ }^{17}$ Señalaron además que sería responsabilidad del encomendero levantar un bohío en un lugar accesible que sirviera de residencia, iglesia — con la inclusión de un altar dedicado a la Virgen y a algún santo- y posada para los españoles e indios que transitaran por aquellas tierras.

\section{El modelo de La Española}

Antes de seguir adelante, conviene analizar la implantación y el desarrollo de la arquitectura hispana en La Española, ya que en cuestión de poco tiempo se convertiría en el modelo a seguir en el continente americano. Hay que recordar que, desde el segundo viaje del almirante Colón (1493-1496), la Corona impuso la colonización de la isla sobre la base de la fundación

15 Ibidem, 1851[1535-1549], I: 164.

16 Muro Orejón, 1956, 423-424.

17 Mena García, 1989, 294-295. 
de nuevos asentamientos urbanos. En este contexto, la arquitectura y el urbanismo asumirían un papel clave en la plasmación de la ciudad hispana en América.

En este incipiente laboratorio caribeño trabajaron un número indeterminado de albañiles, carpinteros y canteros procedentes de la Península. ${ }^{18}$ Los primeros se enrolaron en la segunda expedición colombina, a las órdenes del aparejador Zafra, tomando parte en el trazado y en la construcción de los primeros edificios en piedra de La Isabela (1494), las «casas públicas» como las denominó fray Bartolomé de las Casas. ${ }^{19}$ Junto a este aporte humano, no es raro encontrar en los cargamentos de los barcos con destino a la isla materiales de construcción de variada naturaleza como ladrillos, vigas de madera, tejas y azulejos. En los años siguientes, la presencia de estos maestros constructores se hará notar en las nuevas villas fundadas en la isla, en especial, en Concepción de la Vega (1495) y en la refundación de Santo Domingo (1502) al otro lado del río Ozama. En esta última, por ejemplo, la arquitectura civil tomó ventaja a la religiosa. ${ }^{20}$ Las calles trazadas por Francisco de Garay vieron levantarse los primeros edificios en piedra mientras que los religiosos se hacían de madera y paja, a la espera de la resolución del problema planteado por las bulas. Así, en 1508, Fernando el Católico se quejaba de que «las iglesias que se han hecho en esa isla hasta agora han sido de paja, hanse perdido muchas veces e tantas se han tornado a edificar, de que los pueblos han recibido trabajo y las yglesias están todavía por hacer». ${ }^{21}$

La consolidación de estos templos vino de la mano de la organización eclesiástica de la isla. La primera resultó fallida. La bula Illius fulciti, de 15 de noviembre de 1504, erigió el arzobispado de Santo Domingo (Yaguata) como primado del Nuevo Mundo, y sus dos sedes sufragáneas de Maguá y de Baybúa, todas ellas en la isla de La Española. El documento papal no satisfizo las pretensiones de la Corona, que aspiraba a ejercer el Patronato Real sobre las Indias. En base a este, el rey Fernando, de acuerdo con los tres obispos electos, solicitó al papa Julio II la supresión de las sedes creadas en 1504 y el establecimiento de otras tantas sufragáneas del arzobispado de Sevilla, que finalmente fueron constituidas en la bula Romanus Pontifex de 8 de agosto de 1511. Esta reorganización alumbró los obispados de Santo Domingo y de Concepción de la Vega, en La Española, y el de Puerto Rico.

18 Flores Sasso, 2011.

19 Casas, 1875 [s. XVI], II:21. Palm, 1955, I:47.

20 Palm, 1955, I:80-82.

21 Buschiazzo, 1944, 14. 
A lo largo de 1512, los tres prelados erigirían canónicamente sus respectivas sedes, paso previo a la creación de las primeras catedrales de América.

La creación de estas nuevas sedes catedralicias provocó el inicio de un proceso de dignificación arquitectónica tutelado por la Corona y, en concreto, auspiciado por el obispo Juan Rodríguez de Fonseca (1451-1524), privado y consejero del rey Fernando. ${ }^{22}$ Fonseca fue una personalidad clave para el desarrollo de la primera colonización española en América y un fiel defensor de las prerrogativas de la Monarquía desde que en 1494 se encargó de la preparación del segundo viaje de Colón. Buen conocedor de la arquitectura de su tiempo, se le atribuye la decisión de enviar a La Española maestros constructores contratados por la recién creada Casa de la Contratación (1503) de Sevilla, donde sus hechuras dominaban los cargos más relevantes.

Los primeros artífices enviados a Santo Domingo provenían del taller de la catedral de Sevilla. En 1510 fueron contratados los canteros Juan de Herrera y Ortuño de Bretendón, con sus respectivas cuadrillas, bajo la supervisión de Alonso Rodríguez, maestro mayor de la sede hispalense, quien nunca viajó a la isla caribeña. ${ }^{23}$ Parece que la intención de la Corona era que Rodríguez dirigiera en la distancia y con ayuda de Herrera la construcción de la primera catedral en piedra de América. La elección no podía ser más clara. Los maestros del tardogótico iban a ser los encargados de levantar este templo de acuerdo con las técnicas y tipologías constructivas de la arquitectura hispana de las primeras décadas del siglo XVI, en la que la bóveda de piedra seguía jugando un papel primordial.

Sin embargo, las cosas no tardarían en torcerse. Llegados a Santo Domingo, los canteros hispalenses no pudieron desarrollar su trabajo en la nueva catedral, teniéndose que ocupar de la construcción de viviendas. Estas cuadrillas de constructores volvieron a Sevilla en apenas dos años para continuar su actividad profesional en la catedral. Este fracaso dejó a la catedral de Santo Domingo sumida en la provisionalidad. Cuando el obispo Alejandro Geraldini se incorporó en 1519 a su nueva sede se encontró el templo «construido de palos, de césped, de materia débil, de tablas y de lodo, todo entretejido a manera de arte de jardinero». ${ }^{24}$ En 1521 o 1523, según los autores, se iniciaron los trabajos de construcción de la catedral de

22 Alonso Ruiz, 2007, 97-101.

23 Llaguno y Amírola (1829, I:140-141) erróneamente entendió que Alonso Rodríguez viajó a tierras americanas para trazar la catedral de Santo Domingo. La publicación del documento aclaró la verdadera participación del maestro, en Chacón y Calvo, 1929, 239-248; Utrera, 1929, II:114-116; Muro Orejón, 1935; Rodríguez Estévez, 2010, 313-317.

24 Geraldini, 1631, 267. 
piedra, con la participación primero de Luis de Moya, tal vez el autor de su cabecera, y años después del maestro de cantería Rodrigo Gil de Liendo, quien en 1525 había llegado a la isla con los frailes mercedarios, muy interesados en iniciar el proceso de petrificación de su convento. ${ }^{25}$ Aunque las noticias son escasas, bajo la maestría mayor de este último pudo haberse construido el cuerpo de la iglesia que guarda algunas diferencias con la citada cabecera. ${ }^{26}$

La primera catedral española en América nació bajo el signo de la arquitectura tardogótica, pero muy alejada de su pretendido modelo. $\mathrm{Ni}$ su planta ni su alzado guardan relación con la catedral de Sevilla. Menos aún su tendencia a igualar la altura de sus bóvedas. Tampoco su lenguaje goticista y sus adherencias clasicistas pueden ponerse en relación con un supuesto arquetipo sevillano. El templo de Santo Domingo es el resultado de un tortuoso proceso de adaptación y transformación de la arquitectura del último gótico a las circunstancias locales que fueron tan diferentes a las peninsulares. Estuvo condicionado, en definitiva, por la escasa disposición de recursos económicos, por la carencia de materiales adecuados y por la insuficiente participación de maestros cualificados. Este trasvase de la arquitectura peninsular a La Española no tuvo en cuenta las experiencias vernáculas basadas en la construcción de madera. A diferencia de lo que sucederá en Tierra Firme, el trabajo de la piedra protagonizará la expresión arquitectónica a partir del segundo tercio del siglo XVI.

\section{La arquitectura de Santa María la Antigua}

Casi al mismo tiempo que se constituían las sedes eclesiásticas insulares, la política indiana de la Corona se dirigió a la colonización de la barrera continental y a la búsqueda de un supuesto paso que condujera a las Indias Orientales. Los viajes de Rodrigo de Bastidas (1501-1502) y del almirante Colón (cuarto viaje, 1502-1504) abrieron el camino a las exploraciones de las costas del norte del continente y del istmo centroamericano. No tardarían en seguirles las expediciones de Diego de Nicuesa y Alonso de Ojeda, capituladas con el rey para crear los primeros establecimientos estables en la región de Veragua y en el golfo del Urabá respectivamente. Dada la necesidad de asegurar estos territorios, poblados con indígenas hostiles, se les

25 Palm, 1955, II:29-33.

26 Morales Martínez, 2011, 583-585. 
ordenó que construyeran cuatro asentamientos con otras tantas fortalezas que tendrían que «estar labradas e los cimientos de piedra y lo otro de tapia», en lo que parecen ser las primeras instrucciones de índole constructivo dictadas para Tierra Firme. ${ }^{27}$

Tras no pocos reveses, los supervivientes, comandados por Martín Fernández de Enciso y Vasco Núñez de Balboa, fundaron en noviembre de 1510 Santa María la Antigua del Darién en la costa occidental del golfo del Urabá. ${ }^{28}$ En realidad, fue una fundación oportunista llevada a cabo en un lugar seguro y bien provisto de alimentos, un poblado indígena próximo al cauce del río Tanela gobernado por el cacique Cemaco. ${ }^{29}$ Superada la resistencia de sus pobladores, ocuparon sus bohíos, explotaron sus tierras de labor y crearon la primera iglesia de Tierra Firme, puesta bajo la advocación de la Virgen de la Antigua. Según cuenta Pedro Mártir de Anglería, la iglesia se instaló en «la casa del cacique». ${ }^{30}$ En este primer periodo fundacional, anterior a la expedición de Pedrarias Dávila, debieron de erigirse también una casa o convento franciscano y el pequeño templo de San Sebastián, a los que nos referiremos más adelante.

La organización de la primera estructura eclesiástica del continente fue confirmada por el papa León X con la bula Pastoralis officii debitum exigit de 9 de septiembre de $1513 .{ }^{31}$ Como había sucedido con los obispados caribeños, la nueva sede de Tierra Firme nació como sufragánea del arzobispado de Sevilla. La bula estableció su ámbito de actuación en la «notable provincia que llaman de Bética la nueva, tierra a lo que se

27 Díaz Ceballos, 2015, 47-49.

28 Antes, sin éxito alguno, había visto la luz el primer asentamiento español en el continente, San Sebastián de Urabá, cerca de la actual Necoclí, en la Antioquia colombiana, en Sauer, 1984, 260-262. Mena García, 2011, 130-131.

29 Sobre los intentos de localizar el emplazamiento de Santa María la Antigua, véase García Casares, 2007, 69-73.

30 Anghiera, 1989 [1516], 104.

31 Perdida la bula original expedida por la cancillería papal el 9 de septiembre de 1513 , se conoce su contenido gracias al testimonio - suscrito por el notario apostólico Francisco de Valenzuelade la erección del obispado de Santa María la Antigua, la cual tuvo lugar en Burgos por su obispo fray Vicente de Peraza el primero de diciembre de 1521. En este documento, en latín, se copió literalmente la bula de 1513 «de plomo pendiente con cordones de seda amarilla y colorada según estilo de la Corte Romana sanas y enteras no viciadas ni chanceladas, ni en parte alguna, sospechosas», Burgos, 1 de diciembre de 1521, Archivo General de Indias, Sevilla (AGI), Mapas y Planos, Bulas y Breves, 10. Una traducción al castellano de la erección del obispado, firmada el 6 de mayo de 1623 por Francisco Castañer, se conserva en AGI, Patronato, 1, n. 15, r. 2. En los bularios generales sobre América se recoge la referida al obispado del Darién, en Tobar, 1954 [c. 1695], I:74-75; Morelli, 1776, 90. Se transcribe íntegramente sin indicar su origen en Rojas y Arrieta, 1929, 313-328. Procedente del traslado de una traducción que se conserva en el Archivo Nacional de Colombia, fue recogida en Hernáez, 1879, II:8-13; Morin Couture, 2007, Ib:59-67. 
cree que está en la India», una referencia geográfica equívoca pues en ese mismo año comenzaría a denominarse Castilla del Oro. A Santa María la Antigua, cabeza episcopal, se le otorgó el título de ciudad, como era habitual en estos casos. Su iglesia catedral quedó instituida sobre una capilla ya existente de la que no se ofrecen más detalles, mandando que el futuro prelado designara sus dignidades, canonicatos y prebendas, y ampliara su arquitectura.

Esta tarea quedó encomendada al primer obispo del Darién, el franciscano fray Juan de Quevedo, ${ }^{32}$ hombre de la máxima confianza del rey Fernando y del cardenal Cisneros. ${ }^{33}$ Las instrucciones otorgadas por el monarca a Pedrarias le reservaron un papel político principal en el gobierno de Tierra Firme. ${ }^{34}$ Su presencia obedecería también al deseo de organizar la nueva provincia eclesiástica y su sede catedralicia con una arquitectura digna de su consideración. La estrategia para conseguir esto último fue la misma que se empleó en La Española, recurrir a constructores peninsulares que se trasladarían al istmo para implantar un modelo hispano de arquitectura, no muy diferente al que se estilaba en Sevilla.

Con esta finalidad se embarcaron en la expedición de Pedrarias un número impreciso de maestros constructores, tanto de edificios como de navíos. En una carta de finales de 1515, el gobernador informaba a la Corona que habían fallecido los «aserradores y carpinteros y canteros que llevó». ${ }^{35}$ Asimismo, la Casa de Contratación de Sevilla adquirió todo lo necesario para el culto de los templos darienitas: vestimentas y ornamentos litúrgicos, libros de canto, antifonarios, campanas y un clavicímbano con sus fuelles. En cada una de estas iglesias estaba previsto construir tres retablos que se decorarían con las seis «ymagines de lienço pintados» realizadas para la ocasión en algún taller sevillano cuyo nombre no trasciende en la documentación. Una de estas pinturas pudo ser la copia de la Virgen de la Antigua que presidiría el altar mayor de la catedral ístmica, según González Dávila. ${ }^{36}$

32 Metzler, 1991, I:118-119.

33 Gil Fernández, 1988. García Oro, 1992.

34 Aram, 2008, 72-74. Romoli, 1955, 220.

35 Relación de Pedrarias Dávila, Santa María la Antigua, 28 de noviembre de 1515, AGI, Patronato, 26, r. 5, f. 115 r.

36 El comentario es un tanto impreciso: «Traxeron de Sevilla una copia, y fue la primera que tuvo aquella parte del mundo», en González Dávila, 1655, II:57. Puede referirse a los que dedicaron la iglesia a Santa María la Antigua, según cita unas líneas más arriba, Vasco Núñez de Balboa, Martín Fernández de Enciso o Rodrigo Bastidas, o bien a los miembros de la Armada de Pedrarias. 
Ya en el destino, parece que hubo un intento de organizar la distribución urbana de la sede, que comenzó con el reparto de solares para la iglesia mayor, «para la casa de la contratación y para el cabildo y oficiales». A la primera le correspondieron «4 solares en el medio de la ciudad, que se le dio 2 cavallerías de tierras para la fábrica, y que antes que se hiciese se le dio 150 castellanos de renta para la fábrica, y que con lo que la iglesia tenía se ha hecho una honrada iglesia para allá [...] y está bien ataviada». ${ }^{37}$ Para financiar la construcción de esta «honrada iglesia», la Corona cedió en julio de 1515 sus derechos sobre los diezmos. ${ }^{38}$ Poco más se conoce de este templo, que debió de levantarse de madera y vestirse con los retablos traídos desde Sevilla.

Otro de los objetivos del obispo Quevedo fue la consolidación del convento franciscano fundado en Santa María la Antigua por los religiosos supervivientes de la expedición de Diego de Nicuesa. ${ }^{39}$ Con esta finalidad, le acompañaron seis hermanos en su viaje al Darién, entre los que se ha identificado a fray Diego de Torres y fray Alonso de Escobar. ${ }^{40}$ Del convento franciscano no se tienen muchas noticias. Se supone que su arquitectura debió de ser renovada por los oficiales constructores llegados en la expedición de Pedrarias, al mismo tiempo que se embellecía con los retablos aportados por el obispo.

A finales de 1515, se decía del convento que «está en buen lugar y bien hecho» bajo el gobierno del citado fray Diego de Torres. ${ }^{41}$ Pero las cosas no tardarían en torcerse. Antes de agosto de 1519, sin que se conozcan los motivos, los franciscanos abandonaron la fundación del Darién y

37 Relación de Pedrarias Dávila, Santa María la Antigua, 28 de noviembre de 1515, AGI, Patronato, 26, r. 5, f. 114r.

38 Real cédula de cesión a la iglesia del Darién, Burgos, 20 de julio de 1515, AGI, Panamá, 233, 1. 1, ff. 193r-194r, transcrito en Álvarez Rubiano, 1944, 430-431.

39 El convento había sido fundado antes de la llegada de Pedrarias, Memorial de Rodrigo de Colmenares, Tierra Firme, 1516 o 1517, AGI, Patronato, 26, r. 9, f. 5v. De los cuatro religiosos que formaron parte de la expedición de Nicuesa, se conoce el nombre de tres de ellos: fray Pablo Avilés, fray Fernando de Sepúlveda y fray Andrés de Valdés, en Santa Teresa, 1956, II:93-94. Gómez Canedo, 1957, 103-105.

40 Escobar declaró en la información de méritos del maestrescuela Hernando de Luque que había llegado al Darién en la expedición de Pedrarias. En este mismo documento, fray Andrés de Valdés afirmaba que ya se encontraba en el Darién antes de la llegada de la citada expedición, Méritos y servicios de Hernando de Luque, Panamá, 1524, AGI, Panamá, 61, n. 1. Habría que descartar la presencia de frailes dominicos en la expedición de Pedrarias. Los que figuran en el Catálogo de pasajeros a Indias de 1513, sin que se cite su destino, debieron embarcarse hacia La Española, donde su orden gobernaba un convento. Santa Teresa, 1956, II:214-215. Mena García, 1998, 115.

41 Relación de Pedrarias Dávila, Santa María la Antigua, 28 de diciembre de 1515, AGI, Patronato, 26, r. 5, f. 114r. 
se reubicaron en el convento de su orden en la ciudad de Santo Domingo. Se llevaron consigo todos los ornamentos, retablos y objetos de culto de su iglesia, provocando una respuesta airada del rey, quien les ordenó volver a Santa María la Antigua con todos esos objetos pues «[...] se lo avian dado los vecinos de la dicha cibdad e otras personas de los que en aquellas partes han pasado a nos servir, e de los que están enterrados en la yglesia del dicho monesterio». La denuncia debió de partir de Gonzalo Fernández de Oviedo, quien también se vio perjudicado por esta retirada de los franciscanos, ya que en una de las capillas de la iglesia lucía un retablo donado por el cronista. Se describía como pintado a pincel con las historias del Apocalipsis y de san Juan Bautista en su frente principal, y con tres escudos de su linaje representados en las puertas y en la trasera de este tríptico portátil. ${ }^{42}$ Esta salida de los padres seráficos nada tiene que ver con la fundación de Panamá. Como apunta el padre Severino de Santa Teresa, es muy probable que abandonaran el lugar con el obispo Quevedo en una fecha desconocida de 1518, siguiéndole hasta la capital de La Española. ${ }^{43}$ Sea como fuere, los franciscanos tuvieron que volver a Santa María la Antigua, donde permanecerían hasta 1524, gobernados por el padre fray Alonso de Escobar.

Desde los primeros meses de la fundación consta la existencia de una iglesia dedicada a San Sebastián, sede de la cofradía del mismo nombre a la que pertenecía la mayor parte de la población de Santa María la Antigua. ${ }^{44}$ En su altar mayor, Vasco Núñez de Balboa y sus seguidores juraron no recibir a Diego de Nicuesa ${ }^{45}$ No muy lejos de su puerta, fue atacado Fernández de Oviedo el 19 de septiembre de 1522, quien la sitúa «en cabo e fuera de la çibdad». ${ }^{46}$ Así pues, es muy probable que se tratara de una capilla o ermita puesta bajo la advocación del santo mártir para proteger a los habitantes de los indios flecheros o simplemente de las enfermedades del camino.

La expedición de 1514 a Santa María la Antigua no cumplió con las expectativas previstas por la Corona. El fallecimiento de un número importante de sus integrantes por las enfermedades y el hambre, y el simple abandono de la ciudad de una parte de ellos, en busca de mejores oportunidades, redujo las posibilidades de crear un gran centro urbano en Tierra

42 Reclamación de Gonzalo Fernández de Oviedo, Barcelona, 6 de agosto de 1519, AGI, Indiferente, 420, 1. 8, ff. 108v-109r.

43 Santa Teresa, 1956, II:458-460.

44 Ibidem, 496-500.

45 Fernández de Oviedo, 1852 [1535-1549], II:474.

46 Ibidem, 1853 [1535-1549], III:84. 
Firme. Sucedió lo mismo con su sede episcopal. El regreso a la Península de fray Juan de Quevedo y su posterior fallecimiento en Barcelona el 24 de diciembre de $1519,{ }^{47}$ sumieron al nuevo obispado en la provisionalidad sin que se hubiera institucionalizado su primera organización diocesana. La mayoría de los miembros del capítulo catedralicio, designados de forma interina, había desaparecido; y su catedral seguía alojada en una sencilla construcción de naturaleza desconocida.

\section{La primera catedral de Panamá}

El segundo obispo de Santa María del Darién, el dominico fray Vicente Peraza (1489-1524), fue nombrado el 19 de diciembre de $1520 .{ }^{48} \mathrm{Un}$ año después completó el trabajo que dejó sin realizar su antecesor en el cargo e instituyó la organización eclesiástica de la nueva diócesis según la prerrogativa estipulada en la bula papal de 1513 y el mandato del rey. La escritura fue protocolizada en Burgos ante Fernando de Valenzuela, notario apostólico y secretario personal de Fonseca, obispo de la ciudad castellana y presidente de la Junta de Indias. ${ }^{49}$ Según se expresa en el propio documento, la erección in scriptis se refiere a la diócesis creada en Santa María la Antigua del Darién, sin que exista ninguna alusión a Panamá, fundada en 1519 por Pedrarias Dávila. ${ }^{50}$ Dicho de otro modo, en esta escritura no se formalizó el traslado de la sede catedralicia desde Santa María la Antigua a la nueva capital del Pacífico.

El documento de 1521 se generó en la sala de máquinas de la incipiente administración indiana, que pivotaba en torno a la figura de Fonseca. ${ }^{51}$

47 Mesa, 1986, 38-41.

48 Según la bula Apostolatus officium, transcrita íntegramente en Metzler, 1991, I:154-155. Una transcripción parcial de la misma, publicada en Hernáez, 1879, II:136-137, ha confundido a diferentes autores, ya que en su encabezamiento se dice que el obispo Peraza «erigió la iglesia de Panamá», cosa que pudo ser cierta, pero no a través de la citada bula, en Osorio Osorio, 2001, 92. Figueras Vallés, 2010, 293. Una lectura de esta bula confirma que el nombramiento se hizo sobre la sede de Santa María la Antigua, sin que se mencione para nada a la recién fundada ciudad de Panamá.

49 Erección del obispado de Santa María la Antigua, Burgos, 1 de diciembre de 1521, AGI, Mapas y Planos, Bulas y Breves, 10. Hay un traslado de la traducción de esta escritura, Madrid, 6 de mayo de 1623, AGI, Patronato, 1, n. 15, r. 2. Que el documento se conserve en esta sección del Archivo General de Indias no significa que fuera una bula generada por la cancillería papal, como se insiste en Castillero Calvo, 2006, 99-100.

50 Como se estima en Castillero Reyes, 1943, 2; Osorio Osorio, 2001, 93, que se refuta con la simple lectura del documento, en Ruiz Cajar, 1959, 25.

51 Sobre los hombres de Fonseca en el gobierno indiano, véase Sagarra Gamazo, 1998. 
Para entonces, el prelado castellano había atesorado información suficiente sobre las necesidades de la sede darienita y tenía sobre la mesa los documentos de erección de los obispados caribeños. De hecho, la nueva organización de la iglesia del Darién se asemeja con algunas variaciones a la que se había implantado en la diócesis de Santo Domingo y que no tardaría en extenderse a la cubana. ${ }^{52}$

Quedó constituida una estructura capitular que nada tenía que envidiar a cualquier catedral peninsular, compuesta por seis dignidades (deán, arcediano, chantre, maestrescuela, tesorero y arcipreste), diez canónigos, nueve racioneros (seis de ración entera y tres de media), seis acólitos, seis capellanes y otros tantos oficios (sacristán, organista, pertiguero, ecónomo o procurador, secretario o notario y perrero). Bien es cierto que en el propio documento se preveía una primera fase de asentamiento en la que se suprimirían algunos de estos cargos, como así sucedería. A falta de noticias sobre la verdadera naturaleza del templo que acogería a esta estructura organizativa, no cabe más que pensar que las autoridades eclesiásticas aspiraban a levantar una catedral en unos parámetros muy parecidos a los que se intentaron aplicar en la sede de Santo Domingo, basados en el principio de la monumentalidad que, por supuesto, excluía cualquier utilización de materiales y técnicas autóctonas. Pero, ¿dónde se levantaría esta nueva catedral? Peraza se hizo de rogar. Tras una larga estancia en las Islas Canarias, el nuevo obispo arribó a tierras americanas en la primavera de 1524, muriendo en Panamá el 23 de junio de ese mismo año. ${ }^{53}$ No hay constancia de que le diera tiempo a trasladar la sede. Tampoco que lo hiciera el licenciado Hernando Zelaya, quien dos años antes había llegado a la Antigua con amplios poderes de Peraza para tomar posesión del obispado en su nombre. ${ }^{54}$

52 Escritura de erección del obispado de Santo Domingo en La Española, Burgos, 12 de mayo de 1512, AGI, Mapas y Planos, Bulas y Breves, 9. Había sido protocolizada ante el mismo notario apostólico que en 1521 redactaría la de la sede de Santa María la Antigua. Hernáez, 1879, II:7-13.

53 Sobre su estancia en Canarias, véase Rumeu de Armas, 2002, 215-222; Martínez Marín, 2006, 20-25; Sánchez Rodríguez, 2007, 37-133 y 165-223. La fecha de fallecimiento de Peraza la da Pedrarias en una carta dirigida a su mujer, Isabel de Bobadilla, en la que reconoce que había solicitado al rey la sede vacante en favor de su hijo Francisco, fraile dominico en la ciudad de Santo Domingo. Pedrarias Dávila a doña Isabel de Bobadilla, Panamá, 4 de julio de 1524, Archivo del Conde de Puñonrostro, Madrid (ACP), B-10 J, publicado en Aram, 2008, 355-357. En cuanto al lugar de su muerte, Bartolomé de las Casas, sin mayor precisión, afirmó que Peraza «vivió muy pocos días después de a Panamá llegado». Casas, 1875 [s. XVI], V:205.

54 Zelaya removió de su cargo al deán Juan Pérez de Zalduendo, criatura de Pedrarias, y nombró gobernador de la diócesis al arcediano Rodrigo Pérez, en Santa Teresa, 1956, III:359-360. 
En los primeros años de la década de los veinte, la sede episcopal vivió un corto periodo de cohabitación en el que algunos de sus miembros optaron por asentarse en Panamá mientras que, al menos dos de ellos, los canónigos Lorenzo Martín y Francisco de Arroyo, permanecieron en la selva darienita hasta la definitiva desaparición de Santa María la Antigua en septiembre de $1524 .{ }^{55}$ Entre los primeros habría que contar al famoso maestrescuela Hernando de Luque, que en fecha tan temprana como 1522 figuraba como encomendero en la nueva ciudad. Del deán Juan Pérez de Zalduendo nada se sabe. Es muy probable que pasara a Panamá después del atentado sufrido por Gonzalo Fernández de Oviedo el 19 de septiembre de 1522, siempre antes de la citada información del canónigo Martín. ${ }^{56}$ En ese mismo año, un seglar como Diego de Tobilla, el autor de la desaparecida Barbárica, se presentaba como mayordomo de la iglesia de Panamá, señal inequívoca de la existencia de un templo de naturaleza y categoría desconocidas. ${ }^{57}$ Tal vez fuera el mismo dedicado a la Virgen que, en 1522, servía como lugar ocasional de reunión a Pedrarias, ${ }^{58}$ y que en ese mismo año fue destrozado por un huracán.

El abandono definitivo de la capital darienita supuso de facto la instalación de la sede eclesiástica en Panamá y, por lo tanto, la aceptación implícita de la Corona, dueña del Patronato eclesiástico de las Indias, y de la Santa Sede de esta nueva situación. En todo caso, hay que tener en cuenta tres hechos fundamentales en este asunto. En primer lugar, que la cancillería papal nunca expidió una bula de traspaso de la sede, como pudiera parecer preceptivo y se hizo en otras ocasiones, alguna de ellas en el continente americano. ${ }^{59}$ Tampoco consta, en segundo lugar, que ningún prelado redactara una escritura de erección del obispado de Panamá. ${ }^{60}$ Finalmente, la escritura de constitución de la diócesis del Darién, otorgada por Peraza en 1521, se mantuvo vigente sin ninguna alteración en las tres capitales

55 Información de los méritos y servicios de Lorenzo Martín, Santa María la Antigua, 25 de febrero de 1523, AGI, Patronato, 92, n. 1, r. 2. Transcrito con la signatura antigua (AGI, Patronato, 1-4-3/8) en Medina, 1913, II:325-335.

56 Fernández de Oviedo, 1853 [1535-1549], III:84-85.

57 Luque y Tobilla figuran en el registro de oro de ese año, 1522. Mena, 2011, 417.

589 de junio de 1522, AGI, Justicia, 1042, citado en Jopling, 1994, 159-160.

59 Como bien apunta Morin Couture, 2007, Ia:675. A finales del siglo XVII, Baltasar de Tobar era muy claro al señalar que para llevar a cabo este tipo de traslaciones era necesario un breve particular que, como él mismo indica, no había hallado en el archivo del Consejo de Indias. También se hacía eco de la existencia de un papel anónimo en el que se suponía que había habido bula de traslación durante el pontificado de Adriano VI (1522-1523) o de Clemente VII (1523-1534), sin que se hubiera hallado en el citado archivo. Tobar, 1954 [c. 1695], I:74-75.

60 Santa Teresa, 1956, II:357. 
históricas de Tierra Firme: Santa María la Antigua, Panamá la Vieja y en la nueva ciudad de Panamá. ${ }^{61}$

Para terminar con este apartado, habría que señalar que la orden de la Merced fue la primera comunidad en asentarse en Panamá, protegida por la autoridad del gobernador Pedrarias, quien señaló el sitio para levantar una modesta casa ${ }^{62}$ En lo puramente material, la primera casa mercedaria ya estaba construida en febrero de 1526, cuando estaba a punto de ser ampliada con un bohío de «madera y caña y paja» bajo la supervisión del gobernador, quien había decidido el «traçado donde se haga» con mano de obra indígena de su propiedad. ${ }^{63}$

\section{Berlanga}

La rápida desaparición de Peraza dejó huérfana la sede episcopal. Si se tiene en cuenta que el siguiente obispo del Darién, el tercero, fray Martín de Béjar, nunca llegó a pisar Tierra Firme,${ }^{64}$ y que su sucesor en el cargo, fray Tomás de Berlanga, arribó al istmo panameño en 1534, casi podríamos decir que, desde la salida de Quevedo en 1518 hasta ese último año, la diócesis de Santa María la Antigua vivió una etapa de interinidad, en la que se registraría el citado traslado de su sede a la ciudad de Panamá.

El nuevo obispo de Panamá, fray Tomás de Berlanga, Tomás de Henríquez y Gómez en el siglo, era un buen conocedor de las Indias. Había

61 En dos ocasiones — que se conozca - los prelados panameños solicitaron la copia de la escritura de erección de la diócesis, señal inequívoca de su vigencia. La primera de ellas fue en 1623, a petición del obispo Francisco de la Cámara, para resolver algún contencioso del cabildo catedralicio. La solicitud y la copia de la bula se incluyeron en el libro de registro de las reales disposiciones dirigidas a las autoridades y particulares del distrito de la Audiencia de Panamá, 7 de noviembre de 1623, AGI, Panamá, 237, 1. 14, ff. 237v-248r. Con anterioridad, el obispo Agustín de Carvajal se quejaba de la carencia de un archivo en la catedral y de la pérdida de la citada escritura, posiblemente en alguno de los incendios sufridos por la ciudad, 25 de julio de 1610, AGI, Panamá, 100, n. 64. El obispo Antonio de León solicitó el segundo traslado después de la destrucción de la ciudad el 7 de julio de 1671, siendo remitida una copia el 14 de enero de 1678, AGI, Panamá, 231, 1. 7, ff. 279v-280v y 340v-341r. El primer arzobispo de Panamá, Guillermo Rojas y Arrieta, publicó una orden de Felipe V, fechada en Madrid a 7 de noviembre de 1723, en la que mandaba guardar, cumplir y observar la citada erección. Rojas y Arrieta, 1929, 328.

62 Así se deduce de una confirmación realizada el 24 de abril de 1540, AGI, Panamá, 235, 1. 7, f. 129, citado en Vázquez Fernández, 199, II:611.

63 Carta de Pedrarias Dávila a fray Francisco de Bobadilla, quien en aquel entonces se hallaba en España, Natá, 15 de febrero de 1526, ACP, B-10d, en Aram, 2008, 365.

64 Meseguer Fernández, 1972, 283. Ruiz Cajar, 1959, 29-32. Beltrán de Heredia, 1970, II:518-519. 
formado parte del primer grupo de dominicos que, procedente del convento de San Esteban de Salamanca, donde había profesado en 1508, se había establecido en 1510 en La Española bajo la autoridad del vicario fray Pedro de Córdoba. ${ }^{65}$ Fue pues uno de los frailes fundadores del convento de Santo Domingo, en cuyo púlpito fray Antonio de Montesino dictaría el famoso sermón del primer domingo de Adviento (1511) en defensa de los indios, consensuado en el seno de la comunidad.

Una de las principales preocupaciones del nuevo obispo de Panamá, ya manifiesta en Sevilla antes de partir a su destino, fue la construcción de una catedral de carácter permanente. La petrificación de la arquitectura de la ciudad era, en realidad, una aspiración compartida por sus gobernantes que, en aquellos años, expresaron en diferentes ocasiones su deseo de desterrar los edificios de madera. El incendio, por ejemplo, de la casa de fundición en 1532 «por ser de paja» motivó la solicitud a la Corte de la construcción de una nueva de «piedra, ladrillo o tapia» que evitara este tipo de calamidades. ${ }^{66}$ El gobernador de Tierra Firme, Francisco de Barrionuevo, recién llegado a su nuevo destino en diciembre de 1533, envió una relación al rey en la que describía la modesta arquitectura lignaria que se había encontrado en Nombre de Dios, donde hubo de improvisar la construcción de una casa de aduana y de una iglesia de madera y paja, y en Panamá. ${ }^{67}$

Los documentos de la época revelan que el principal problema para conseguir este objetivo era la carencia de profesionales y de materiales de construcción. En una fecha tan temprana como 1531, la Corona intentaba reclutar en la capital hispalense oficiales relacionados con los oficios de la construcción, al parecer, por la sucesión de llamamientos con poco éxito. Berlanga era consciente de estas dificultades, pues las había tenido que superar durante su priorato del convento de Santo Domingo de La Española, cuando promovió la consolidación de su arquitectura. ${ }^{68}$

El nuevo obispo salió hacia su destino a mediados del mes de septiembre de 1534. La expedición hizo escala en Santo Domingo, donde Berlanga contrató al mallorquín Antón García, oficial «diestro en toda cosa [...] de carpintería y albañilería» que había emigrado a la isla caribeña antes de

65 Figueras Vallés, 2010, 63 y ss.

66 A petición de Gonzalo Fernández de Oviedo, veedor de fundiciones, se expidió una cédula real para construir una nueva casa de fundiciones, Medina del Campo, 25 de abril de 1532, AGI, Panamá, 234, 1. 5, f. 24r bis. El propio Oviedo había solicitado hacer una fortaleza de piedra. Ibidem, f. 24v bis. 67 Francisco de Barrionuevo, gobernador, al emperador, Panamá, 23 de diciembre de 1533, AGI, Patronato 194, r. 18, en Pacheco et al., 1884, 501-512.

68 Figueras Vallés, 2010, 94. 
1516. ${ }^{69}$ Es muy probable que lo conociera de su primera (1511-1528) o segunda (1530-1531) etapa en Santo Domingo, y que incluso lo pudiera haber contratado para las obras del convento dominico. De su trayectoria profesional en España, nada se conoce. Se le relaciona con algunos pagos realizados en 1521 por diferentes trabajos en la fortaleza de Santo Domingo, y es muy probable — como avanzó Palm - que se trate de la misma persona que en 1534 se trasladó a Cartagena de Indias, a través de Nombre de Dios, para dar la traza de su catedral, destruida en 1552 por un incendio. ${ }^{70}$

En abril de 1535, Antón García ya se encontraba en Panamá, al tiempo que el cabildo catedralicio y la Audiencia solicitaban al rey el permiso necesario para construir la nueva catedral con su ayuda. ${ }^{71}$ En el mismo documento se informaba que la Audiencia de Santo Domingo había denunciado al maestro por abandonar la isla sin solicitar su licencia. Las fuerzas vivas de Panamá, deseosas de contar con su trabajo, solicitaron al rey algún beneficio para que García se asentase en la capital del istmo y pudiera traer a su familia. El rey accedió a incluirle en el reparto de tierras y solares de la ciudad como un vecino más. ${ }^{72}$ En la citada solicitud no se mencionaba cómo tendría que ser el nuevo edificio diseñado por García. Por algún motivo desconocido, el mallorquín no pudo desplegar sus habilidades en Panamá, ya que, en abril de 1537, Berlanga, vuelto de su viaje al Perú, se quejaba al rey de que la iglesia mayor «está muy vieja», indicando la necesidad de que se labrase una nueva de piedra. ${ }^{73}$

Antes de partir a su misión peruana, el prelado envió una larga carta al emperador en la que le planteaba una reforma profunda de los caminos que atravesaban el istmo y unían los dos mares. ${ }^{74}$ Propuso el abandono de Nombre de Dios, «cueva de ladrones y sepultura de peregrinos», y su traslado a la desembocadura del río Chagres, desde donde las embarcaciones podrían remontar su cauce hasta una nueva población, Venta de Cruces, que

69 Si bien en el Catálogo de pasajeros figuran dos entradas a nombre de Antón García y su mujer Teresa Jiménez, la primera el 16 de noviembre de 1512 y la segunda el 19 de agosto de 1516, esto podría indicar la realización de dos viajes en fechas muy próximas o que la primera salida nunca se llevó a cabo por motivos desconocidos. Catálogo de pasajeros..., 1940, I:64 y 153-154.

70 Marco Dorta, 1945, 524. Palm, 1955, I:89. Flores Sasso, 2009, I:471.

71 Carta del deán y cabildo de la iglesia de Panamá al rey, Panamá, 25 de abril de 1535, AGI, Patronato, 194, r. 28, f. 114.

72 Real cédula al gobernador de Tierra Firme, Madrid, 11 de marzo de 1536, AGI, Panamá, 235 , 1. 6, f. 4 v.

73 Carta de fray Tomás de Berlanga al rey, Panamá, 5 de abril de 1537, AGI, Patronato, 194, r. 38.

74 Carta de fray Tomás de Berlanga al rey, Panamá, 22 de febrero de 1535, AGI, Patronato, 194, r. 27, ff. 109-110. Véase además Figueras Vallés, 2010, 209-220. 
se convertiría en un puerto fluvial apenas a una jornada de Panamá. También planteó el abandono del poblado costero de Acla y la fundación de la nueva Acla en el interior, en una zona más apropiada para la agricultura y la ganadería. Se situaría justamente a una jornada de la vieja Acla y a otra de Cruces y de Panamá. Pero quizás lo más sorprendente - y motivo de que nos detengamos en su propuesta - es que Berlanga auguraba que este poblado «fuese tan bueno y mejor que Santo Domingo, y aun digo, que allí había de estar la iglesia catedral». ${ }^{75}$ Resulta, así pues, un tanto sorprendente que cuando Antón García se hallaba en Panamá para construir la nueva catedral, su promotor, el obispo Berlanga, propusiera crear una nueva ciudad, sede del obispado, en el interior del territorio. Detrás de esta iniciativa, que nunca fue hecha realidad, se puede descubrir el interés del prelado por la actividad agrícola como fuente de riqueza de un país.

Para cerrar este capítulo, restaría mencionar el proyecto de Berlanga de fundar un convento de su religión en Panamá, que sería la segunda fundación dominica en el istmo, ya que desde 1519 la orden regentaba una casa en Nombre de Dios, dependiente de la vicaría provincial de la isla de La Española. ${ }^{76}$ Esta última había sido fundada por fray Reginaldo de Pedraza, quien desde 1524 acompañaría a Francisco Pizarro en su conquista del Perú. Con este objetivo, Berlanga solicitó al rey, antes de partir a su destino, limosnas para ornamentos y para edificar un aposento temporal a la espera de construir el cenobio dominico «de tapia o piedra». ${ }^{77}$ La casa de Panamá debió de construirse en un sitio «que estaba señalado para un monasterio de la Orden de Santo Domingo», no muy lejos de la plaza. El oidor de la nueva Audiencia de Panamá, creada en 1538, Francisco Pérez de Robles, se resistió a esta ocupación, siendo llamado al orden por el rey. ${ }^{78} \mathrm{~A}$ fray Pedro de Aguilar, provisor de los dominicos, hay que atribuirle la iniciativa de crear una «casa de teja» en la ciudad donde se hospedaron los diferentes grupos de frailes dominicos que fueron llegando al istmo, la mayoría camino del

75 Ibidem, f. 110r.

76 Medina, 1913, I:24. Ariza, 1963, 12. Martínez Marín, 2004, 16-20.

77 Reales cédulas a los oficiales reales de Tierra Firme, Toledo, 20 de febrero de 1534, AGI, Panamá, 234, 1. 5, ff. 132v y 139v-140r. También pidió emplear en su construcción una cantidad de oro que el citado Pedraza había depositado en el arca de tres llaves de Panamá, Real cédula al gobernador y oficiales de la provincia de Tierra Firme, Toledo, 19 de julio de 1534, ibidem, f. 173.

78 Al parecer, fray Tomás de Berlanga había mandado derribar una casa levantada en un solar delineado para el convento de Santo Domingo, lo que había provocado la denuncia del oidor Robles, llegado a Panamá en 1538, y hombre que atesoraría un gran poder en este tiempo, Real cédula al doctor Francisco de Robles, Madrid, 18 de julio de 1539, AGI, Panamá, 235, 1. 7, f. 58v. 
Perú. ${ }^{79}$ Este carácter pasajero de la ocupación de la casa impidió que los dominicos enraizaran en la ciudad durante el pontificado de fray Tomás de Berlanga. La fundación del convento de Panamá tendría que esperar todavía algunos años. En 1565, el capítulo provincial de Perú aprobó la fundación del primer convento en la ciudad y el cierre de la casa de Nombre de Dios. Los primeros dominicos llegarían poco tiempo después con fray Domingo Pérez a la cabeza, instalándose en una amplia manzana situada al norte de la plaza mayor. ${ }^{80}$

\section{A la manera española}

La vieja iglesia que hacía las veces de catedral, descrita por Berlanga en abril de 1537, no sobrevivió a los incendios de 1538 y 1540 . El primero comenzó el 20 de marzo en una casa de paja que servía de taller de herrería del platero Tomé García, al parecer, por un descuido de uno de sus esclavos. Se propagó con gran celeridad destruyendo toda la ciudad a excepción de cinco o seis casas. ${ }^{81}$ Sin tiempo a recuperarse de tan grave pérdida, el 15 de febrero de 1540 se volvió a quemar Panamá. Esta vez el incendio se inició en las casas del contador Peinado, ardiendo «la mayor y mejor parte de la ciudad»: muchas casas principales del entorno del puerto y de la plaza, las casas del cabildo que aún no se habían terminado de construir, el hospital de San Sebastián, la residencia del obispo y su iglesia mayor, de la que tan solo se pudieron salvar el «Santísimo Sacramento, las ymágenes y algunos ornamentos». ${ }^{82}$ Es muy probable que Berlanga viajara a la Península antes de este segundo incendio con la intención de retomar el proyecto de construir una nueva catedral de piedra.

Las gestiones del obispo ante el rey dieron sus frutos. Por un lado, una vez más, se recurrió a organizar una pequeña expedición formada por maestros de la construcción contratados en Sevilla en agosto de 1540 y por

79 Probanza de los méritos y servicios de fray Pedro de Aguilar, Panamá, 17 de marzo de 1544, AGI, Panamá, 100, n. 4, ff. 4-11.

80 Las fuentes difieren sobre la fecha de este asentamiento. Una probanza del convento de Santo Domingo sitúa esta fundación en 1566, Panamá, 18 de julio de 1586, AGI, Panamá, 103; mientras que sería en 1571, según la "Descripción histórica" de 1607, recogida en Relaciones históricas..., 1908, 202.

81 Carta de los oficiales reales de Tierra Firme al rey, Nombre de Dios, 12 de agosto de 1538, AGI, Patronato, 194, r. 43, f. 209r. Véase Castillero Calvo, 2006, 691-692.

82 Carta del doctor Francisco de Robles, Panamá, 16 de febrero de 1540, AGI, Patronato, 194, r. 53 , f. 263 . 
trabajadores esclavos, bien surtida de ornamentos litúrgicos y demás objetos necesarios para el nuevo templo principal. ${ }^{83} \mathrm{El}$ rey accedió a financiar la obra con 300.000 maravedíes pagados en tres anualidades, ${ }^{84}$ y a recuperar una vieja cédula de 1521, nunca llevada a efecto, para la compra de órganos y un reloj. ${ }^{85}$

Berlanga, por otro lado, consiguió que el rey aceptara el cambio de ubicación de la futura catedral y que le cediera un solar en la delantera de la plaza destinado «para casa de cabildo [...] donde ella [la futura iglesia] tuviera vista e honrara e adornara mucho la plaça e a esa ciudad». ${ }^{86} \mathrm{Un}$ reciente estudio multidisciplinar, basado en dos campañas arqueológicas (2003 y 2018), que exhumaron un relevante conjunto de enterramientos primarios, y en un exhaustivo estudio histórico, ha situado este primer templo catedralicio en el sudoeste de la plaza de Panamá la Vieja, muy cerca de la actual línea de costa, con su cabecera perfectamente orientada. ${ }^{87}$ Sus autores han planteado además una hipótesis muy convincente sobre los motivos que originaron este cambio de ubicación, entendiendo que la devastación provocada por los incendios se convirtió en una oportunidad para solucionar los problemas generados por la ocupación humana de la línea de costa. La desaparición del manglar, necesario para consolidar el terreno, habría desprotegido las construcciones situadas en la calle de la playa hasta el punto de hacerlas peligrar ante el avance de las aguas del mar. La decisión de llevar el nuevo templo a lado oriental de la plaza en una disposición norte-sur, con su presbiterio mirando al mar, debe ser entendida, además, como una manera de poner en valor su presencia física, su «vista», tal vez porque el obispo soriano albergaba la posibilidad de levantar un templo de grandes proporciones, acorde a la idea de monumentalidad asociada al modelo de catedral hispana, que difícilmente podría haberse extendido en el solar primitivo. Además, hay que pensar que el terreno rocoso en el que finalmente fue establecida favorecería la cimentación del edificio en el que estaría previsto emplear la bóveda de piedra. No parece que existiera

83 Archivo Provincial de Sevilla, Protocolo 13.463, oficio 20, legajo 2. ${ }^{\circ}$, ff. 336, 338 y 352-353, Sevilla, 1540. Reales cédulas a los oficiales reales de Tierra Firme, Madrid, 30 de junio de 1540, AGI, Panamá, 235, 1. 7, ff. 151r-152r y 154r-155v. Véase Marco Dorta, 1945, 524-527.

84 Real cédula a los oficiales reales de Tierra Firme, Madrid, 30 de junio de 1540, AGI, Panamá, 235, 1. 7, f. 152.

85 Real cédula a los oidores de la Audiencia de Panamá, Madrid, 15 de abril de 1540, AGI, Panamá, 235, 1. 7, ff. 120r-121v.

86 Real cédula a los oidores de la Audiencia de Panamá, Madrid, 15 de abril de 1540, ibidem, f. 122.

87 Hernández, Martín y Aram, 2020. 
ninguna intencionalidad simbólica relacionada con la liturgia en esta nueva ubicación, sino más bien una cuestión de oportunidad al poder contar con un solar disponible en un lugar destacado de la plaza principal. ${ }^{88}$

Si la pérdida de la línea costera pudo haber provocado una merma importante del tejido urbano de Panamá, no olvidemos una segunda circunstancia que condicionó su desarrollo: la presencia de una laguna en el interior de la ciudad formada «cuando llueve en el invierno que dura todo el año». Según los oficiales reales, «por esto como por estar a la otra parte la mar el pueblo no es cuadrado ni puede tener más de dos calles». ${ }^{89}$ Términos muy parecidos a los empleados por Cieza de León para describir la forma de la ciudad y su emplazamiento insano por aquellos mismos años: «Tiene poco circuito donde está situada, por causa de un palude o laguna, que por la una parte la ciñe». ${ }^{90}$ Coincidiendo, pues, con la creación de la audiencia y pocas semanas después del primero de los incendios que azotaría Panamá, la administración real ordenó la desecación de este humedal que comprometía su desarrollo urbano y la salud de sus vecinos, casi al mismo tiempo que su primer oidor proyectaba construir las casas de la audiencia y su propia residencia en la pequeña península rocosa situada junto al puerto de la ciudad, no muy lejos del altozano donde años después se levantaría la nueva catedral.

Este cambio de ubicación de la catedral ha de ser evaluado en el contexto urbano de Panamá. En los últimos años, la arqueología ha venido a confirmar que la ciudad destruida por Morgan se acercaba más al plano diseñado en 1586 por Bautista Antonelli (Museo Naval de Madrid) que al realizado en 1609 por Cristóbal de Roda (Archivo General de Indias), asumiendo de esta manera que la vieja Panamá poseía un trazado regular sin atisbos de ortogonalidad. ${ }^{91}$ La comparación de este último con el damero perfecto de Natá, bien conocido por haberse conservado su acta de fundación (1522), ofrece demasiadas incógnitas. ${ }^{92}$ La principal se refiere a la disparidad proyectual de estas dos fundaciones realizadas en apenas tres

88 Resulta difícil de entender que, en 1540, Berlanga tuviera en cuenta las Instructionum fabricae, et supellectilis ecclesiasticae Libri II (1577), de san Carlos Borromeo (1538-1584), a la hora de establecer el presbiterio de su nueva iglesia mirando al sur, como se apunta en Castillero Calvo, 2006, 231-232.

89 Real cédula a los oidores de la Audiencia de Panamá, Valladolid, 13 de mayo de 1538, AGI, Panamá, 235, 1. 6, ff. 215v- 216r.

90 Cieza de León, 1553, f. II.

91 Mena García, 1992, 88-89. Tejeira Davis, 1996, 53-54.

92 Sobre el acta de fundación de Natá, véase Castillero Calvo, 1972, 55-75. En base a este documento, véase la reconstrucción de su trazado ortogonal en Tejeira Davis, 1996, 62-65. 
años de diferencia por Pedrarias Dávila. Tal vez los cambios introducidos en 1540 puedan explicar esta notable discordancia. Por un lado, la primitiva ubicación de la catedral panameña al sur de su plaza principal, documentada recientemente, es la misma que tuvo la iglesia principal de Natá, aunque se desconocen las características y la orientación de este primitivo templo. La práctica desaparición de la calle de la Playa en Panamá, por efectos del mar, por otro lado, podría explicar la falta de ortogonalidad de su trazado y su necesidad de adaptarse a un terreno irregular condicionado por la presencia de la ya mencionada laguna.

Por desgracia, los dos barcos de la expedición del obispo Berlanga naufragaron en enero de 1541 a diez leguas de las costas de Acla, ahogándose los canteros y albañiles contratados en Sevilla para trabajar en las obras de la nueva catedral. ${ }^{93}$ También se perdieron todos los enseres y materiales destinados a ella. Fracasó así el intento más serio de petrificar la arquitectura de la catedral de Panamá y dotarla de monumentalidad. Berlanga tendría que contentarse con una nueva iglesia de madera que pocos meses después sería levantada gracias al esfuerzo de su fiel colaborador fray Pedro de Aguilar, provisor de la orden, quien también era chantre de la catedral en 1544 . De este templo solo se conoce que tenía 140 pies y que se había edificado «de madera recia y cubierto de teja», sustituyendo a la que «antes estava de paja e bohio viejo maltratado». ${ }^{94}$

\section{La arquitectura de la madera}

El naufragio en las costas de Acla puso a las autoridades eclesiásticas de frente a sus propias limitaciones y, en cierto modo también, a una forma de hacer arquitectura revestida de valores simbólicos. Este desastre no solo acabó con las pretensiones de monumentalizar la catedral de Panamá al modo hispano, sino también, aunque parezca una paradoja, con la provisionalidad que había supuesto la instalación del principal templo de la ciudad en un bohío. En otras palabras, la construcción basada en la simple recolección de materiales, unida en esencia al medio natural, fue sustituida por una arquitectura de la madera con un pretendido carácter permanente. En efecto,

93 Carta de fray Tomás de Berlanga al rey, Acla, 4 de febrero de 1541, AGI, Patronato, 194, r. 60.

94 Probanza de los méritos y servicios de fray Pedro de Aguilar, Panamá, 17 de marzo de 1544, AGI, Panamá, 100, n. 4, ff. 4-11. 
la arquitectura religiosa sucumbió al empuje del sector maderero que se había hecho fuerte en la construcción civil gracias a la abundante materia prima existente en los bosques de la región, caracterizada por la alta calidad de especies como el cedro, la caoba, el mangle, el cocobolo, el guayacán o el níspero, y al desarrollo de una industria transformadora capaz de fabricar las piezas necesarias para construir casas sólidas y duraderas, gracias también a la paulatina incorporación de varios tipos de clavazón metálica. ${ }^{95}$

Esta tecnología de la madera llegó al Nuevo Mundo de la mano de los carpinteros de armar o de obra de afuera y de los carpinteros de ribera, estos últimos tan importantes en la construcción naval que facilitó la navegación por el Mar del Sur. Aunque no conocemos los nombres ni las procedencias de la mayoría de ellos, los primeros profesionales de la madera arribaron al continente - como ya se ha señalado — en la armada de Pedrarias, alcanzando una visibilidad social muy relevante en Panamá. Así, por ejemplo, los carpinteros de ribera y los calafates formaron la cofradía más antigua de la ciudad. ${ }^{96}$

Las escasas noticias documentales que nos han llegado de la catedral construida por el padre Aguilar permiten hacernos una idea muy somera de su arquitectura. No hay duda de que toda ella se construyó en madera y tuvo una única nave que, andando el tiempo, sería insuficiente para dar cobijo a la feligresía del lugar. Cabe imaginar que este espacio limitado debió de cubrirse con una armadura de par y nudillo, como tantas viviendas de la época. Sería el mismo templo que el nuevo obispo de la ciudad, fray Manuel de Mercado, se encontró en 1578 en un estado de conservación bastante deficiente, ${ }^{97}$ y que, en el escaso tiempo que permaneció al frente de la sede episcopal, trató de sustituir — sin éxito, una vez más— por una construcción de piedra.

La ansiada petrificación de la arquitectura religiosa aún tendría que esperar hasta las primeras décadas del siglo XVII. Y cuando llegó, lo haría de forma parcial, alcanzando solamente a los muros que delimitaban estos espacios sagrados. Las nuevas iglesias de Panamá se seguirían cubriendo con sencillas armaduras de madera sostenidas por horcones separadores de sus naves. Para entonces, la bóveda de piedra se había convertido en un recurso menor empleado para proteger ámbitos de pequeño tamaño como capillas

95 Mena García, 1992, 115-122. Castillero Calvo, 2019, 107-109.

96 Hernández, Martín y Aram, 2020.

97 Carta de fray Manuel de Mercado al rey, Panamá, 15 de mayo de 1578, AGI, Panamá, 100, f. 73 . 
o aljibes. Quizás lo más destacado de este nuevo concepto arquitectónico, que pronto se extendería por todo el istmo, fue el empleo de los citados horcones apoyados sobre pedestales de piedra que impedían la pudrición de sus cabezas en contacto con el suelo, ${ }^{98}$ una solución cuando menos ajena —en cuanto a su disposición — a la carpintería de armar española. Siendo un elemento básico de la construcción lignaria, el pie derecho en pocas ocasiones había sido impostado de esta manera en la arquitectura religiosa hispana, más allá de servir de apoyo a pequeñas estructuras como los coros de las iglesias o las galerías de los claustros conventuales constituidos con este material. Por lo general, las iglesias españolas de tres naves cubiertas con armaduras de madera se solían separar con arcadas de piedra alineadas longitudinalmente o, más raramente, con simples soportes columnados de este material, siempre constituyendo ámbitos muy reducidos.

La disponibilidad de estos largos y robustos palos, procedentes de los bosques tropicales de la región ístmica, permitió desarrollar una arquitectura caracterizada por ofrecer unos espacios unitarios y diáfanos, aunque limitados en su altura. Las iglesias de horcones se seguirían construyendo en los siglos posteriores, dejando ejemplos tan interesantes como la iglesia de la Merced de la ciudad de Panamá o los templos parroquiales de Parita, Natá (fig. 3) o Los Santos, estos dos últimos de cinco naves.

Queda por dilucidar cuál fue el origen de esta fórmula constructiva que tanto recuerda la disposición de los horcones en los bohíos indígenas. Resulta tentador suponer que algunos de estos bohíos, desaparecidos para siempre, pudieran haber adaptado su sencilla arquitectura a las necesidades espaciales de un templo religioso como una catedral, incorporando tal vez pasillos o naves separadas por horcones, y que a partir de 1540, los materiales procedentes de la recolección, tramados sin apenas transformación, hubieran dejado paso a una arquitectura de armar a la española abastecida por una industria maderera especializada en la construcción civil. A la espera de la tan ansiada petrificación de la arquitectura religiosa que, en realidad, nunca llegaría a los sistemas de cubierta, los horcones — denominados

98 Nótese que el empleo del término «pedestal» se hace desde su significado estricto como fundamento o pie (Diccionario de la lengua española) de los horcones, sin ninguna connotación relacionada con el orden clásico. También podrían definirse como «basas» con el mismo sentido, aunque su forma alta y alargada se acerca más a la primera denominación. Los pedestales de los horcones de la iglesia de la Merced de Panamá, rescatados en una acertada intervención, serían un buen ejemplo de estas piezas que soportan directamente los palos de madera. No puede decirse lo mismo de los pedestales de la iglesia de Natá, hoy conservados en un jardín cercano, al haber sido sustituidos por bloques de hormigón que cumplen la misma función. 
FIGURA 3

INTERIOR DE LA IGLESIA DE NATÁ

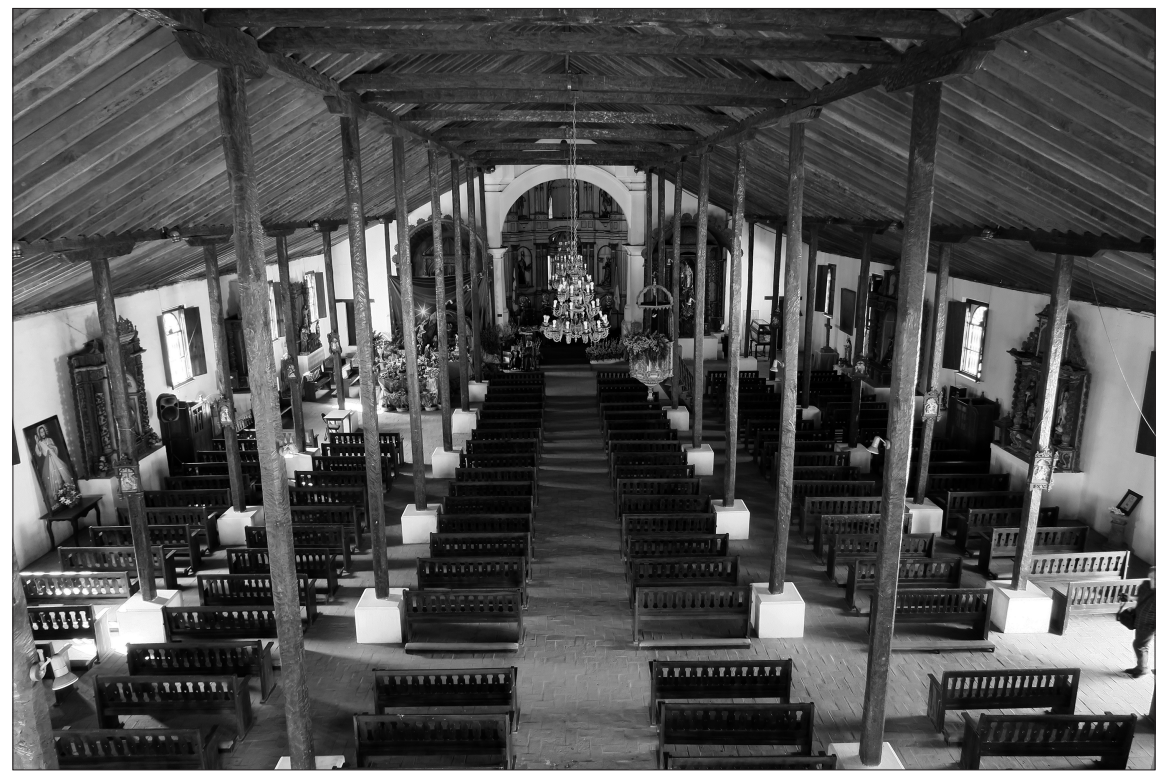

Fuente: Fotografía del autor.

«pilarotes o estantes de maderas valientes» por fray Juan de Fonseca ${ }^{99}$ — se habrían mantenido para separar las naves de los templos católicos apeados sobre pedestales. Por desgracia, no existen testimonios escritos ni evidencias arqueológicas que confirmen esta hipotética evolución de la arquitectura colonial panameña.

\section{Referencias bibliográficas}

Alonso Ruiz, Begoña, "“Mezclar el mundo". Los primeros constructores castellanos en el Caribe», en Sazatornil Ruiz, Luis (coord.), Arte y mecenazgo indiano: del Cantábrico al Caribe, Gijón, Trea, 2007, 89-104.

99 El testimonio del franciscano fue recogido por Juan Requejo Salcedo, «Relación histórica y geográfica de la provincia de Panamá. Año 1640», en Relaciones históricas...,1908, 51. 
Álvarez Rubiano, Pablo, Pedrarias Dávila. Contribución al estudio de la figura del "gran justador", gobernador de Castilla del Oro y Nicaragua, Madrid, Consejo Superior de Investigaciones Científicas, 1944.

Anghiera, Pietro Martire de, Décadas del Nuevo Mundo, Madrid, Ediciones Polifemo, 1989 [1. ${ }^{\mathrm{a}}$ ed. 1516].

Aram, Bethany, Leyenda negra y leyendas doradas en la conquista de América. Pedrarias y Balboa, Madrid, Fundación Jorge Juan/Marcial Pons Historia, 2008.

Ariza, Alberto E., Los dominicos en Panamá, Bogotá, Convento-Seminario de Santo Domingo, 1963.

Beltrán de Heredia, Vicente (ed.), Cartulario de la Universidad de Salamanca, Salamanca, Universidad, 1970-1972, 6 vols.

Borromeo, Carlo, Instructionum fabricae, et supellectilis ecclesiasticae Libri II, Roma, Typographum Illustriss. Cardinalis S. Praxedis Archiepiscopi, 1577.

Buschiazzo, Mario J., Estudios de Arquitectura Colonial Hispano Americana, Buenos Aires, Editorial Guillermo Kraft, 1944.

Casas, Bartolomé de las, Historia de las Indias, Madrid, Imprenta de Miguel Ginesta, 1875-1876 [orig. s. XVI], 5 vols.

Castillero Calvo, Alfredo, Fundación y orígenes de Natá, Panamá, Instituto Panameño de Turismo, 1972.

Castillero Calvo, Alfredo, Sociedad, economía y cultura material: Historia urbana de Panamá La Vieja, Panamá, Patronato Panamá Viejo, 2006.

Castillero Calvo, Alfredo, Arquitectura, urbanismo y sociedad. Vivienda, calidad de vida y mentalidades en el Panamá colonial, 2. ${ }^{a}$ ed., Panamá, Editora Novo Art, 2019.

Castillero Reyes, Ernesto J., «Datos para la Historia de la Curia Panameña», Lotería, 29, Panamá, octubre de 1943, 2 y 4.

Catálogo de pasajeros a Indias durante los siglos XVI, XVII y XVIII, Sevilla, Archivo General de Indias/Imprenta Editorial La Gavidia, 1940-1986.

Chacón y Calvo, José María, Cedulario cubano. Los orígenes de la colonización, Madrid, Compañía Ibero-Americana de Publicaciones, 1929.

Cieza de León, Pedro, Parte primera de la chronica del Perú, Sevilla, Casa de Martín de Montesdoca, 1553.

Díaz Ceballos, Jorge, «La configuración de la red urbana de Castilla del Oro, 15081522», en Rey Castelao, Ofelia y Mantecón Movellán, Tomás A. (eds.), Identidades urbanas en la monarquía hispánica (siglos XVI-XVIII), Santiago de Compostela, Universidad de Santiago de Compostela, 2015, 45-65.

Fernández de Oviedo, Gonzalo, Historia general de las Indias, Sevilla, Juan Cromberger, 1535 .

Fernández de Oviedo, Gonzalo, Historia general y natural de las Indias, Islas y Tierra-firme del mar Océano, Madrid, Real Academia de la Historia, 18511855 [orig. 1535-1549], 4 vols. 
Figueras Vallés, Estrella, Fray Tomas de Berlanga. Una vida dedicada a la fe y a la ciencia, Soria, Ochoa Editores, 2010.

Flores Sasso, Virginia, «Técnicas constructivas utilizadas en las bóvedas de las primeras construcciones españolas en Santo Domingo», en Huerta Fernández, Santiago (coord.), Actas del Sexto Congreso Nacional de Historia de la Construcción: Valencia, 21-24 de octubre de 2009, Valencia, Instituto Juan de Herrera, 2009, t. I, 467-478.

Flores Sasso, Virginia, «Primeros constructores españoles en el Nuevo Mundo, 1492-1550», en Alonso Ruiz, Begoña (ed.), La arquitectura tardogótica castellana entre Europa y América, Madrid, Sílex, 2011, 609-619.

García Casares, Juan, Historia del Darién: cuevas, cunas, españoles, afros, presencia y actualidad de los chocoes, Panamá, Editorial Universitaria Carlos Manuel Gasteazoro, 2007.

García Oro, José, «Fray Juan de Quevedo, OFM, primer Obispo de Tierra Firme. Un confidente del Cardenal Cisneros», Archivum Franciscanum Historicum, 85, Roma, 1992, 38-75.

Geraldini, Alexandro, Itinerarium ad regiones sub aequinoctiali plaga constitutas, Roma, Guilelmi Facciotti, 1631.

Gil Fernández, Juan, «Los años sevillanos de Fray Juan de Quevedo: Nuevos documentos», Archivo Ibero-Americano, 189-192, Madrid, 1988, 741-753.

Gómez Canedo, Lino, «Primeros intentos de evangelización franciscana en Tierra Firme (1508-1553)», Archivum Franciscanum Historicum, 50, Roma, 1957, 99-118.

González Dávila, Gil, Teatro eclesiástico de la primitiva Iglesia de las Indias Occidentales, Madrid, Diego Díaz de la Carrera,1655, 2 vols.

Gould, Alice B., Nueva lista documentada de los tripulantes de Colón en 1492, Madrid, Real Academia de la Historia, 1984.

Gutiérrez, Samuel A., Arquitectura panameña: descripción e historia, Panamá, Autoridad del Canal de Panamá, 1966.

Hernáez, Francisco Javier (ed.), Colección de bulas, breves y otros documentos relativos a la iglesia de América y Filipinas, Bruselas, Imprenta de Alfredo Vromant, 1879, 2 vols.

Hernández Mora, Iosvany; Martín, Juan G. y Aram, Bethany, «The First Cathedral on America's Pacific Coast», Historical Archaeology, Germantown (Maryland), 2020 [en prensa].

Jopling, Carol F., Indios y negros en Panamá en los siglos XVI y XVII. Selecciones de los documentos del Archivo General de Indias, Antigua, Centro de Investigaciones Regionales de Mesoamérica, 1994.

Llaguno y Amírola, Eugenio, Noticias de los arquitectos y arquitectura de España desde su restauración. Ilustrada y acrecentada con notas, adiciones y documentos por don Agustín Ceán Bermúdez, Madrid, Imprenta Real, 1829, 4 vols. 
Marco Dorta, Enrique, «La arquitectura en Panamá, Colombia y Venezuela», en Angulo Íñiguez, Diego (ed.), Historia del Arte Hispanoamericano, Barcelona, Salvat, 1945, tomo I, segunda parte.

Martín, Juan G., «Excavaciones arqueológicas en el Parque Morelos (Panamá la Vieja)», Arqueología de Panamá la Vieja. Avances de investigación, agosto de 2002, 203-229.

Martínez Marín, José, Dominicos en Panamá, Panamá, Imprenta Articsa, 2004.

Martínez Marín, José, Dominicos en Panamá. Biografías, Panamá, Imprenta Articsa, 2006.

Medina, José Toribio, El descubrimiento del Océano Pacífico. Vasco Núñez de Balboa, Hernando de Magallanes y sus compañeros, Santiago de Chile, Imprenta Universitaria, 1913, 2 vols.

Mena García, Carmen, «La autonomía legislativa en Indias: las leyes de Burgos y su aplicación en Castilla del Oro por Pedrarias Dávila», Revista de Indias, 186, Madrid, 1989, 283-353.

Mena García, Carmen, La Ciudad en un cruce de caminos (Panamá y sus orígenes urbanos), Sevilla, Escuela de Estudios Hispano-americanos de Sevilla, 1992.

Mena García, Carmen, Sevilla y las flotas de Indias. La gran armada de Castilla del Oro (1512-1514), Sevilla, Universidad y Fundación el Monte, 1998.

Mena García, Carmen, El oro del Darién. Entradas y cabalgadas en la conquista de Tierra Firme (1509-1525), Sevilla, Fundación Pública Andaluza Centro de Estudios Andaluces, 2011.

Mesa, Carlos E., Primera diócesis en Tierra Firme. Santa María La Antigua del Darién, Bogotá, Consejo Episcopal Latinoamericano, 1986.

Meseguer Fernández, Juan, «El P. Francisco de Lisboa, O.F.M., visitador de la provincia de la Concepción, 1520. Fr. Martín de Béjar», Archivo Ibero-Americano, 126, Madrid, 1972, 279-284.

Metzler, Josef (ed.), America Pontificia primi saeculi evangelizationis 1493-1592. Documenta pontificia ex registris et minutis praesertim in Archivio Secreto Vaticano existentibus, 2 vols., Ciudad del Vaticano, Libreria Editrice Vaticana, 1991,

Morales Martínez, Alfredo J., «La proyección del tardogótico castellano. La catedral de Santo Domingo», en Alonso Ruiz, Begoña (ed.) La arquitectura tardogótica castellana entre Europa y América, Madrid, Sílex, 2011, 573-589.

Morelli, Cyriaci [Muriel, Domingo], Fasti Novi Orbis et Ordinationum Apostolicarum ad Indias pertinentium Breviarum cum adnotationibus, Venecia, Antonio Zatta, 1776.

Morin Couture, Alfredo, Apuntes de historia de la Iglesia de Panamá. Periodo colonial, Panamá, Editorial Mariano Arosamena, 2007, 2 vols.

Muro Orejón, Antonio, «Alonso Rodríguez, primer arquitecto de las Indias», en Arte en América y Filipinas, 1, Sevilla, 1935, 76-88. 
Muro Orejón, Antonio, «Ordenanzas reales sobre los indios. (Las leyes de 15121513)», Anuario de Estudios Americanos, 13, Sevilla, 1956, 417-471.

Osorio Osorio, Alberto, Fray Juan de Quevedo, primer obispo de Tierra Firme, Panamá, Club Kiwanis, 2001.

Pacheco, Joaquín F.; Cárdenas, Francisco de y Torres de Mendoza, Luis (dir.), Colección de documentos inéditos relativos al descubrimiento, conquista y colonización de las posesiones españolas en América y Oceanía, sacados en su mayor parte del Archivo Real de Indias, tomo XLI, Madrid, Imprenta de Manuel G. Hernández, 1884.

Palm, Erwin Walter, Los monumentos arquitectónicos de la Española con una introducción a América, Santo Domingo, Universidad, 1955, 2 vols.

Peguero, Luis Joseph, Historia de la conquista de la isla Española de Santo Domingo, Trasumptada el año de 1762, Traducida de la Historia General de las Indias escrita por Antonio de Herrera, Santo Domingo, Museo de las Casas Reales, 1975 [orig. 1762-1763], 2 vols.

Prieto Vicioso, Esteban, «La arquitectura indígena en La Española», Clío: Órgano de la Academia Dominicana de la Historia, 175, Santo Domingo, 2008, 113-150.

Prieto Vicioso, Esteban, «Relación de Rodrigo de Escobedo sobre su visita a la villa de Guacanagarí en 1492», Clío: Órgano de la Academia Dominicana de la Historia, 191, Santo Domingo, 2016, 255-278.

Relaciones históricas y geográficas de América Central, Madrid, Librería general de Victoriano Suárez, 1908.

Rodríguez Estévez, Juan Clemente, «El maestro Alonso Rodríguez», en Alonso Ruiz, Begoña (ed.), Los últimos arquitectos del Gótico, Madrid, Marta Fernández-Rañada, 2010, 271-360.

Rojas y Arrieta, Guillermo, Reseña histórica de los Obispos que han ocupado la Silla de Panamá desde su fundación hasta nuestros días, Lima, Tipografía Salesiana, 1929.

Romoli, Kathleen, Vasco Núñez de Balboa descubridor del Pacífico, Madrid, Espasa Calpe, 1955.

Ruiz Cajar, Críspulo, «La jerarquía eclesiástica en Panamá, durante el siglo XVI», Missionalia hispánica, 46, Madrid, 1959, 5-86.

Rumeu de Armas, Antonio, «Fray Vicente Peraza, obispo visitador de las Islas Canarias y prelado de la diócesis de Santa María del Darién (Panamá)», Anuario de Estudios Atlánticos, 48, Las Palmas de Gran Canaria, 2002, 215-222.

Sagarra Gamazo, Adelaida, Burgos y el gobierno indiano: la clientela del obispo Fonseca, Burgos, Caja de Burgos, 1998.

Sánchez Rodríguez, Julio, Fray Vicente Peraza O. P., Las Palmas de Gran Canaria, Nueva Gráfica, 2007.

Santa Teresa, Severino, Historia documentada de la Iglesia en Urabá y el Darién, desde el descubrimiento hasta nuestros días, 5 vols., Bogotá, Biblioteca de la Presidencia de la República, 1956-1957. 
Sauer, Carl O., Descubrimiento y dominación española en el Caribe, México, Fondo de Cultura Económica, 1984.

Serrano y Sanz, Manuel, Orígenes de la dominación española en América, Madrid, Casa Editorial Bailly Bailliere, 1918.

Soraluce Blond, José Ramón, «El bohío cubano: arquitecturas de cubierta vegetal en El Caribe», El Pajar. Cuaderno de Etnografía Canaria, 14, Las Palmas de Gran Canaria, 2003, 144-147.

Tejeira Davis, Eduardo, «Pedrarias Dávila y sus fundaciones en Tierra Firme, 1513-1522. Nuevos datos sobre los inicios del urbanismo hispánico en América», Anales del Instituto de Investigaciones Estéticas, 69, México D. F., 1996, 41-77.

Tobar, Balthasar de, Compendio bulario índico, 2 vols., estudio y edición de Manuel Gutiérrez de Arce, Sevilla, Escuela de Estudios Hispano-Americanos, 1954 [c. 1695].

Torre Revello, José, «Obras de arte enviadas al Nuevo Mundo en los siglos XVI y XVII», Anales del Instituto de Arte Americano de Investigaciones Científicas, 1, Buenos Aires, 1948, 132-144.

Utrera, fray Cipriano de, Santo Domingo. Dilucidaciones históricas, Santo Domingo, Secretaria de Estado de Educación, Bellas Artes y Cultos, 1927-1929, 2 vols.

Vázquez Fernández, Luis, «Cedulario mercedario en su relación con el Nuevo Mundo: 1518-1599», en Presencia de la Merced en América, Actas del I Congreso Internacional (Madrid, 30 de abril - 2 de mayo de 1991), Madrid, Revista «Estudios», 1991, v. II, 597-659. 